Prace Filologiczne. Literaturoznawstwo 10(13) 2020

ISSN 2084-6045

e-ISSN 2658-2503

Creative Commons: Uznanie autorstwa 3.0 PL (CC BY)

DOI: $10.32798 /$ pflit.581

\title{
WYBRANE ASPEKTY RECEPCJI TWÓRCZOŚCI HENRYKA SIENKIEWICZA NA ŚLĄSKU. REKONESANS*
}

Reception of Henryk Sienkiewicz's Works in Upper Silesia. A Reconnaissance

\author{
EWA KOSOWSKA \\ Uniwersytet Śląski w Katowicach, Polska \\ E-mail: ewa.kosowska@us.edu.pl \\ ORCID: 0000-0003-4994-1517
}

\begin{abstract}
While exploring the reception of Henryk Sienkiewicz's works in Upper Silesia, the author ponders the following problems: 1) the impact of Katolik [Catholic], a newspaper written in Polish, on the preparation of recipients to the reading of the novels; 2) the influence of the message contained in the novels (the so called case of von Olszewski's testament); and 3) artistic inspirations and ideological polemics with Sienkiewicz's message (Jan Kupiec from Łąka). The paper argues that the reception of Sienkiewicz's works by individual readers brought up in foreign cultural context can be remoulded not only into symbols of the revival of past familial connections with the motherland but can also become an origin of the fascination with the very phenomenon of national identity restitution.
\end{abstract}

Keywords: Henryk Sienkiewicz, Jan Kupiec, national culture

\section{Streszczenie}

Omawiając recepcję twórczości Henryka Sienkiewicza na Śląsku, autorka podejmuje trzy kwestie: 1) znaczenia polskojęzycznej gazety „Katolik” w przygotowaniu odbiorców do lektury powieści, 2) wpływu przesłania zawartego w powieściach Sienkiewicza (tzw. przypadek testamentu von Olszewskiego) oraz 3) inspiracji artystycznych i polemik ideowych z przesłaniem Sienkiewicza (Jan Kupiec z Łąki). Artykuł pokazuje, że odbiór powieści Sienkiewicza przez pojedynczych czytelników wychowywanych w obcym kontekście kulturowym nie tylko bywa przekształcany w symbole odradzania dawnych rodzinnych związków z ojczyzną, ale i staje się zaczynem fascynacji samym zjawiskiem restytucji świadomości narodowej.

Słowa kluczowe: Henryk Sienkiewicz, Jan Kupiec, kultura narodowa

${ }^{*}$ Publikacja artykułu dofinansowana przez Uniwersytet Warszawski. 


\section{Na Śląsku, czyli gdzie?}

Po zakończeniu I wojny światowej przeważająca część Śląska znalazła się w granicach odrodzonego państwa polskiego. Przestały obowiązywać historyczne podziały, które w przeszłości doprowadziły do podziału regionu pomiędzy Prusy i Austrię. Należy pamiętać, że obszar Dolnego oraz część Górnego Śląska weszły w skład państwa pruskiego już na mocy traktatu kończącego tzw. wojny śląskie w latach czterdziestych XVIII wieku (dlatego mówienie o „Śląsku pod zaborem” jest formalnym przekłamaniem). Po roku 1815 wyłoniona została tzw. rejencja opolska, pozostająca w granicach państwa pruskiego do roku 1945. Obejmowała ona znaczną część tzw. Górnego Śląska. Natomiast tereny dawnego Księstwa Cieszyńskiego nazywano Śląskiem austriackim. Śląsk pruski, podobnie jak zagarnięte obszary Wielkopolski, stopniowo germanizowano. Na obszarach wiejskich utrzymanie rodzimej mowy i tradycyjnej obyczajowości było łatwiejsze, bo w niewielkim stopniu wpływało na efekty produkcji rolnej, ale organizacja przemysłu i związana z nią mobilność dużych grup ludzkich wymuszała posługiwanie się językiem, który członkom wieloetnicznego społeczeństwa ułatwiał zarówno codzienną komunikację, jak i kształtowanie nowych nawyków, kompetencji i umiejętności. Wraz z budową nowoczesnego państwa niemieckiego rozwijanego pod rządami Otto von Bismarcka następowała wzmożona unifikacja różnych form życia codziennego; w Prusach, a potem na terenie całej Rzeszy, świadomie tępiono przejawy językowej i kulturowej odrębności (Kulturkampf), co spotykało się z ostrą reakcją Polaków w Królestwie i Austrii ${ }^{1}$.

Jednocześnie, istniejący od początków XIX wieku obowiązek szkolny doprowadził do stosunkowo szybkiej likwidacji analfabetyzmu i otworzył przedstawicielom różnych warstw społecznych dostęp do książek i czasopism, w tym także do twórczości Henryka Sienkiewicza. Niewątpliwie część Ślązaków mogła zapoznać się z nią za pośrednictwem tłumaczeń niemieckich². Część czytywała utwory

${ }^{1}$ Godny uwagi w tym kontekście jest stosunek Sienkiewicza do tzw. „kwestii pruskiej”, wielokrotnie omawiany. Cf. m.in. L. Ludorowski, Obywatelska stużba Sienkiewicza, w: Studia Sienkiewiczowskie, t. 1: Henryk Sienkiewicz. Biografia - Twórczość - Recepcja, red. L. Ludorowski, H. Ludorowska, Lublin 1998, s. 11-28; M. Kosman, Wobec carskiej cenzury i pruskiego Drang nach Osten, w: idem, Henryka Sienkiewicza wizja Polski wspaniałej. Studia i szkice, Poznań 1999; L. Ludorowski, Antypruska publicystyka Henryka Sienkiewicza, Lublin 1996.

${ }^{2} \mathrm{~W}$ tłumaczeniu na niemiecki ukazały się, często wkrótce po wydaniach polskich, Listy z podróży do Ameryki, 1876-1878 (jako Briefe aus Amerika); Szkice węglem, 1880 (Kohlenzeichnungen); Za chlebem, 1880 (Ums liebe Brot); Latarnik, 1882 (Der Leuchtturmwärter); Ogniem i mieczem, 1884 (Mit Feuer und Schwert); Potop, 1886 (Sturmflut); Pan Wołodyjowski, 1888 (Pan Wolodyjowski, der kleine Ritter); Bez dogmatu, 1891 (Ohne Dogma); Listy z Afryki, 1891-1892 (Briefe aus Afrika); Rodzina Połanieckich, 1895 (Familie Polaniecki); Quo vadis?, 1896; Krzyżacy, 1900 (Kreuzritter); W pustyni $i$ w puszczy, 1911 (Durch Wuste und Wildnis); Legiony, 1917 (Die Legionen). Odrębną grupę stanowiły publikowane w czasopismach opowiadania: 
pisarza w oryginale. Popularność reportaży i powieści uczyniła z Sienkiewicza postać publicznie znaną, co umożliwiło mu z czasem coraz bardziej otwarte zaangażowanie w doraźną pomoc dla głodujących Ślązaków ${ }^{3}$, w akcje promujące dorobek koryfeuszy kultury narodowej i podejmowanie tematów mających wydźwięk antygermanizacyjny ${ }^{4}$. Tak między innymi odczytywano nowelę $Z$ pamiętnika poznańskiego nauczyciela, skądinąd ostrzegającą także przed skutkami rusyfikacji, tak odbierano Bartka Zwycięzcę.

Z pamiętnika poznańskiego nauczyciela, 1879 (Aus den Erinnerungen eines Posener Lehrers); Janko Muzykant, 1880 (Janko, der Musikant); Bartek Zwycięzca, 1882 (Bartel, der Sieger). Podaję na podstawie: Brockhaus Enzyklopädie in vierundzwanzig Bänden. Neunzehnte, völlig neu bearbeitete Auflage, T. 20: Sci-Sq, Mannheim 1963, s. 257. Analiza recepcji tych utworów na Śląsku jest niemożliwa w ramach jednego artykułu. Dlatego ograniczam się do Krzyżaków i Trylogii.

${ }^{3}$ J. Birkenmajer, Sienkiewicz a Śląsk, „Zaranie Śląskie” 1934, nr 4. Artykuł ten, który ukazał się także jako odrębny druk w Cieszynie w 1935 r., jest w całości poświęcony rekonstrukcji kolejnych etapów zaangażowania redaktorów i publicystów „Gazety Polskiej”, w tym zwłaszcza Sienkiewicza i Edwarda Leo, w akcję pomocy dla głodujących Ślązaków. Zaraza ziemniaczana i związana z nią klęska głodu, jaka dotknęła Górny Śląsk w latach 1879-1881, wywołały poruszenie w Królestwie. W „Gazecie Polskiej” ukazały się odezwy nawołujące do pomocy. Niektóre z nich, publikowane anonimowo, J. Birkenmajer na podstawie analizy stylistycznej uznaje za artykuły interwencyjne pióra Sienkiewicza. Uczony przypomina także list Karola Miarki, który w odpowiedzi na akcję dziękował redaktorom „Gazety Polskiej”. List ten opublikowany został 2 grudnia 1879 roku w numerze 270. pisma: „Szanowni Rodacy. Wiadomość, że gazety warszawskie poruszyły myśl o zbieraniu ofiar dla nieszczęśliwych Górno-Szlązaków, czytaliśmy łzawem okiem. Opisać nie mogę wrażenia, jakie ta wiadomość wywołała w całym Górno-Szląsku. Zaprawdę, okropna na Górnym Szląsku panuje nędza, wylewy rzek zniszczyły wszelką nadzieję żniw; nieustanne deszcze na wiosnę i podczas lata zepsuły zboże i jarzyny, w niektórych okolicach nisko położonych ziemniaki zgniły zupełnie, że ich nawet nie dobywano z ziemi, a klęska tym dokuczliwsza, ponieważ lud nasz żywi się przeważnie ziemniakami i kapustą, która się także nie udała. Stagnacja w handlu i przemyśle, brak odbytu żelaza i węgla i z tej przyczyny zarobku pomnażają biedę, grożąc głodową śmiercią ubogiemu ludowi, wszystkim zaś warstwom zaraźliwymi chorobami, które w latach 1846-1849 trzecią część mieszkańców umorzyły na Górnym Szląsku. Jeżeli kiedy i gdzie bądź pomoc była potrzebną, to zapewne dla Górnego Szląska. Bracia! Ratujcie rodaków, którzy za każdą pomoc czy w pieniądzach czy w odzieży czy w zbożu, mące czy innej żywności, wdzięcznie się modlić będą za łaskawych dobrodziejów, tym więcej, że to pomoc od rodaków. Bóg łaskawy, który nagradza i kubek wody podany pragnącemu, zapewne i wam zapłaci hojnym błogosławieństwem. Upraszamy wszystkie pisma polskie o łaskawe umieszczenie niniejszej odezwy. Dyrektor Zarządu Górno-Szląskiego Towarzystwa Włościan oraz Komitetu głodowego dla Górno Szlązaków - Karol Miarka”.

${ }^{4} \mathrm{~W}$ liście do baronowej Berthy von Suttner, zapraszającym do podpisania petycji w sprawie prześladowania Burów, Sienkiewicz pisał: „A jednak odezwy podpisać nie mogę. Nie mogę, albowiem wydaje mi się jakąś niesłychaną ironią, czy też jakimś potwornym bałamuctwem taki kierunek humanitarnych idei i taki stan najszlachetniejszych nawet umysłów, w którym potępia się tak gorąco objawy przemocy pod biegunem południowym i odczuwa się całym sercem nieszczęścia tak odległe, a nie widzi się i nie słyszy o najbliższych i najgłębszych. [...] Oczy wasze błąkają się po przestworach Oceanu, i wzrok leci na krańce ziemi, a przecie Poznańskie, Śląsk i Prusy Zachodnie leżą tuż obok Was!"; H. Sienkiewicz, List do baronowej Suttner, w: Pisma Henryka Sienkiewicza, Dwie tąi i inne nowele, Warszawa 1912, s. 79-80. 


\section{Znaczenie „Katolika”}

Na popularyzację twórczości Sienkiewicza wśród Górnoślązaków mógł mieć wpływ „Katolik”, odkupiony przez Karola Miarkę i wydawany po polsku w latach 1869-1931, najpierw w Hucie Królewskiej (Chorzowie), a potem w Bytomiu i Mikołowie 5 . Od 1880 roku pismo wychodziło w ośmiu tysiącach egzemplarzy, w kilka lat później już w nakładzie ponaddziesięciotysięcznym. Miarka konsekwentnie upominał się w nim o prawo do posługiwania się na Śląsku językiem polskim, między innymi wystosowując w roku 1872 list otwarty w tej sprawie do Bismarcka. Kilkanaście lat później, w roku 1895, Sienkiewicz pisze wnikliwą analizę postawy i sposobów działania niemieckiego kanclerza, akcentując jego pragmatyzm i rolę w zjednoczeniu Niemiec, a jednocześnie wskazując polityczne i moralne konsekwencje stosowania zasady „siła przed prawem”6.

\section{Sukces Krzyżaków}

Sława Sienkiewicza niewątpliwie docierała na Śląsk. "Gazeta Opolska"7 od roku 1897 (nr 8) do 1900 (nr 86) publikowała Krzyżaków w przeróbce Bernarda Milskiego, gdańskiego księgarza. Sienkiewicz wydał zgodę na adaptację powieści „dla ludu” i ukazała się ona w tej formie na Pomorzu: w „Gazecie Gdańskiej” w latach 1897-1900 (numery 81-88), a także we fragmentach w „Gazecie Ludowej” w Ełku w 1899 roku, w „Gazecie Toruńskiej” w latach 1899-1900 i „Gazecie Grudziądzkiej” w latach 1908 (nr 29) i 1910 (nr 149) ${ }^{8}$. Po lekturze jeden z czytelników nadesłał ze Śląska list do pisarza, opublikowany w „Kurierze Codziennym":

Byłbym został Niemcem, a i dzieci moje tyż, a mam ich aż 11, ale ksiądz mi dali pańskie „Krzyżaki”. Dopiero ci zobaczyłem, jak oni nas tumanią. Oho - teraz my wiemy, a i dzieci

${ }^{5}$ E. Kosowska, Zagubiony kontekst, w: Na obrzeżach polityki, red. M. Kosman, cz. 1, Poznań 2002, s. 7-14.

${ }^{6}$ „Wszystko jedno, czy ks. Bismark powiedział lub nie powiedział: »siła przed prawem«. Vox populi przypisuje mu to hasło, widzi w niem niejako treść jego myśli i widzi słusznie, albowiem było ono niewątpliwie duchem i wyrazem całej jego polityki. I zasadę tę nie tylko ks. Bismark przeprowadzał sam, lecz dzięki niesłychanym powodzeniom ubrał ją w pozory praktycznej prawdy, upowszechnił ją, narzucił ludzkości i obniżył poziom moralny europejskiego życia tak mocno, jak nie uczynił tego nikt od całych stuleci”; Pisma Henryka Sienkiewicza..., s. 71.

${ }^{7}$ Pismo polityczno-społeczne, założone przez Bronisława Koraszewskiego, wydawane w latach 1890-1923 w Opolu. „Gazeta Opolska” miała 14 dodatków, w tym „Rolnik”, „Gość Niedzielny” i „Psikus”.

${ }^{8}$ H. Kosętka, O recepcji „Krzyżaków” Henryka Sienkiewicza, w: W stulecie „Krzyżaków” Henryka Sienkiewicza, red. L. Ludorowski, H. Ludorowska, Kielce 2000, s. 316. Jednakże o sprzedawanie Krzyżaków w wydaniu gdańskim w Krakowie firma Gebethner i Wolf wytoczyła księgarzowi Franciszkowi Wiśniewskiemu proces zakończony sukcesem pozywających; Rozprawa o „Krzyżaków” w krakowskim trybunale karnym, „Czas” 1901, nr 279. 
tyż wiedzieć będą: kto my. Więc pokornie kłaniam się Panu i powiem, choć byście kazali w ogień, to pójdę w ogień9 9

Sukces Krzyżaków przyczynił się do próby okazania Sienkiewiczowi bardziej materialnych dowodów wdzięczności. W 1908 roku Alfred von Olszewski ${ }^{10}$ sporządził w Genewie testament, w którym spadkobiercą znacznego majątku czynił Sienkiewicza $w$ dowód uznania dla perswazyjnej mocy jego powieści. Pisarz miał wejść w posiadanie legatu wówczas, gdy naturalni spadkobiercy testatora nie wypełniliby warunków przejęcia spadku:

Przeto wolą moją jest by dzieci do roku 30 swego życia złożyły 3 egzaminy: z języka, kultury i historii Polski, przed egzaminatorem wiarygodnym i przeze mnie ustanowionym. Życzeniem moim jest, by córka przyjęła wiarę katolicką. W razie niespełnienia warunków moich postanawiam majątek mój, to jest dobra wsi Warmątowice (287 ha) z dochodem rocznym marek 12927 i drugi majątek, 140 ha z dochodem 5834 marek, nadto pałac w Warmątowicach z parkiem 8 ha, wart milion marek w złocie, zapisać Henrykowi Sienkiewiczowi, nobliście. Żywię nadzieję, że po śmierci mojej, choć część majątku zgromadzonego przez ród Olszewskich na Śląsku powróci nad Wisłę i przyczyni się do odrodzenia narodowego ducha.

Cytowany tekst jest prawdopodobnie tłumaczeniem dużej części niemieckiego oryginału ${ }^{11}$. Warmątowicki graf zmarł 3 kwietnia 1909 roku. Oryginał jego testamentu nie zachował się ${ }^{12}$. Jak zgodnie twierdzą badacze, Sienkiewicz dowiedział się o tym legacie z prasy i nie zamierzał go przejmować wbrew woli naturalnych spadkobierców. Wdowa po von Olszewskim, Gabriela, przekonała go, że ze względu na intelektualną niesprawność syna wypełnienie warunków testamentu jest niemożliwe. Pisarz i jego rodzina oficjalnie zrzekli się prawa do spadku ${ }^{13}$, a uzasadniając tę decyzję Sienkiewicz w liście do adwokata Tadeusza Kraushara pisał: „W żadnym razie nie zagrabiłbym majątku sierot,

\footnotetext{
9 „Kurier Codzienny” 1900, nr 353. Cf. także A. Adamek-Świechowska, „Krzyżacy” i budzenie polskości, „Niedziela Ogólnopolska” 2009, nr 30, s. 33.

${ }^{10}$ Informacje na ten temat są wielokrotnie powtarzane, m.in. „Głos Warszawski” 1909, nr 290; T. Kraushar, Testament Olszewskiego, „Kurier Warszawski” 1924, nr 300; A. C., Testament von Olszewskiego, „Kurier Warszawski” 1932, nr 314; J. Krzyżanowski, Henryk Sienkiewicz. Kalendarz życia i twórczości, uzupełniła i oprac. M. Bokszczanin, Warszawa 2012, s. 390; Z. Antkowiak, Legenda warmatowicka. Rzecz o zapisie Alfreda Olszewskiego dla Henryka Sienkiewicza, Wrocław 1978, passim; J. Szczublewski, Żywot Sienkiewicza, Warszawa 1989, s. 391-392. Na obecność tego wątku w listach pisarza wskazuje Maria Bokszczanin; J. Krzyżanowski, Henryk Sienkiewicz. Kalendarz..., s. 313.

${ }^{11}$ B. Ratter, Korzenie von Olszewskiego, http://solidarni2010.pl/11497-bozena-ratter-korzenievon-olszewskiego.html?PHPSESSID=8d19c419652c42b7bf5f685fd6fab085 (d.d. 10.10.2018).

${ }^{12}$ A. Adamek-Świechowska, „Krzyżacy” $i$ budzenie polskości....

${ }^{13}$ Za poradą prawników zatrzymano 30000 marek jako depozyt gwarantujący spełnienie przez spadkobierców woli testatora. Suma ta uległa dewaluacji; syn i córka przeznaczyli ją na potrzeby Uniwersytetu Ludowego w Odolanowie. Cf. J. Krzyżanowski, Henryk Sienkiewicz. Kalendarz..., s. 312.
} 
gdyż do Polski i polskiej idei nie ciągnie się nikogo groźbą wyzucia z ziemi odziedziczonej po ojcach"14. W rzeczywistości dzieci najprawdopodobniej nigdy nie dowiedziały się od matki, potomkini pruskiego rodu junkierskiego, o ostatniej woli ich ojca.

\section{Znaczenie języka Trylogii}

Powieści Sienkiewicza były atrakcyjne nie tylko ze względu na wielowątkowość i wartką akcję. Ceniono je także za walory formalne, w tym uwrażliwienie czytelników na piękno staropolszczyzny. Ta odmianka języka polskiego, praktycznie niemożliwa do przełożenia na inne języki, stała się swoistą podstawą narodowego idiolektu, w którym można było nie tylko wyrazić szeroką skalę rozmaitych uczuć, ale też przekazać przemyślenia historiozoficzne i ideologiczne, dać wyraz postawie krytycznej i odbudowywać/budować poczucie ponadstanowej wspólnoty. Zawikłana barokowa składnia, w jakiej formułowane były sądy odnarratorskie, podszyte ironicznym dystansem do tragicznej rzeczywistości, przysparzała kłopotów nie tylko tłumaczom, ale i cenzorom. Sienkiewicz niczego nie nazywał wprost, a jednocześnie bezpośrednio dotykał problemów, które najżywotniej obchodziły każdego Polaka. Język jego powieści, świadomie archaizowany, a przecież podówczas doskonale rozumiany, uwodził poczuciem swojskości, a na poziomie wyobrażeń ewokowanych przez piękno słowa i prostotę stylu konstruował poczucie więzi i utrwalał wartość narodowej wspólnoty. Stał się swoistym kokonem, w którym bezpiecznie dojrzewały nastroje patriotyczne, a zarazem twierdzą, w której można było je chronić przed podejrzliwością cenzury i ewentualną interwencją stróżów ówczesnego ładu. Pisarzowi udało się przekształcić język w bastion polskości, nic więc dziwnego, że chętnie szukali tam azylu Polacy poddawani presji wynarodowienia.

\section{Czy Sienkiewicz miał wpływ na twórczość Jana Kupca?}

Wypracowany przez pisarza styl stał się przedmiotem naśladowania. Wśród autorów mniej lub bardziej udanych przeróbek i parodii spotykamy zarówno znakomitych satyryków, jak i nieco naiwnych naśladowców, z całą powagą imitujących formę, której tajniki umykały imitatorom. Można by postawić pytanie, do której z tych grup - jeśli w ogóle - należałoby zaliczyć Jana Kupca (1841-1909), pisarza, poetę i działacza oświatowego, urodzonego w Bielsku, a związanego z Łąką koło Pszczyny. Droga życiowa Kupca - z jednej strony po części reprezentatywna dla ówczesnego Ślązaka, z drugiej niebanalna z uwagi na talent, intensywne samokształcenie i instynkt polityczny - mogłaby stać się kanwą

${ }^{14}$ H. Sienkiewicz, Listy, oprac., wstęp i przyp. M. Bokszczanin, t. 3, cz. 1: [do Tadeusza Kraushara], Warszawa 2007, s. 301-305; cf. ibidem, [do Sienkiewiczowej Marii z Babskich], s. 414-416. 
atrakcyjnej powieści ${ }^{15}$. Zainteresowania etnograficzne sprawiły, że nazywano go „chłopskim Kolbergiem” (zbierał pieśni ludowe od 1856 roku). Od lat siedemdziesiątych, po powrocie z wojny francusko-pruskiej, zaczął czytać polskie czasopisma i książki docierające na Śląsk. Z czasem sam publikował, prezentując własną wizję znaczenia ludu śląskiego w dziejach Polski. Nie zachowały się żadne dokumenty wskazujące bezpośrednio na to, że Kupiec czytywał powieści Sienkiewicza. Wydaje się jednak mało prawdopodobne, by ich nie znał, zważywszy na zainteresowanie książką polską, zaangażowanie polityczne i działalność publicystyczną. Próba udowodnienia tej tezy wymagałaby odrębnych, pogłębionych badań. Tutaj, tytułem rekonesansu, chciałabym jedynie odwołać się do kilku tropów sugerujących, iż Sienkiewicz miał w Kupcu uważnego i krytycznego czytelnika.

Chodzi o co najmniej dwa poematy zachowane w spuściźnie poety. Jeden z nich, Sejmik w Jassach, był publikowany w „Górnoślązaku”, katowickiej gazecie codziennej, od 26 maja do 14 lipca 1904 roku. Kolejne fragmenty ukazywały się najpierw dwa razy w tygodniu, a z czasem niemal każdego dnia. Niedawno wydano go też w formie książkowej ${ }^{16}$. Jassy to niewielkie miasto leżące w dorzeczu Prutu, niegdyś w Mołdawii, a obecnie w północno-wschodniej Rumunii. Tu właśnie Kupiec umieścił akcję swojego utworu. W Jassach zbierają się magnaci polscy niezadowoleni z zapisów Konstytucji 3 maja, która wbrew ich interesom minimalizuje różnice stanowe i godzi w przywileje szlacheckie. Dyskutują więc nad możliwościami jej odrzucenia. Są wśród nich nie tylko magnaci, w tym przyszli targowiczanie ${ }^{17}$, ale także mityczny król Popiel, znani z Potopu hetmani (Hieronim Radziejowski i Jerzy Lubomirski) oraz poseł z Upity, Władysław Siciński, który pierwszy zerwał sejm polski, korzystając z prawa liberum veto. To nadaje utworowi wymiar symboliczny - elity wszystkich epok są odpowiedzialne za zdradę ojczyzny na rzecz interesów partykularnych. W podtekście znajduje się wyraźna sugestia, że jakiekolwiek heroizowanie takiej postawy jest ze wszech miar nieuzasadnione. Tym samym przesłanie

${ }^{15}$ Cf. W. Nawrocki, Jan Kupiec - poeta z Łąki, Katowice 1963.

${ }^{16}$ J. Kupiec, Sejmik w Jassach, wstęp i oprac. D. Rott, A. Spyra, Pszczyna 2010. Profesorowi Dariuszowi Rottowi dziękuję w tym miejscu za udostępnienie bibliofilskich wydań faksymiliów poematów Jana Kupca.

${ }^{17}$ [Jan] Suchorzewski, [Kazimierz] Rzewuski, [Ignacy] Massalski, Józef Ankiewicz, Szymon Kossakowski, Ksawery Branicki, Adam Poniński, [Gabriel] Podoski (przeciwnik konfederacji barskiej), [Stanisław Szczęsny] Potocki, Antoni Czetwertyński, [Józef Jakub] Szwejkowski, [Paweł] Hulewicz, [Ignacy] Zagórski, [Faustyn?] Kobylański, [Józef] Wielhurski, Józef Kossakowski, [Jan?] Złotnicki, Michał Gliński, Dyzma Bończa Tomaszewski. W nawiasach kwadratowych podaję imiona rekonstruowane na podstawie źródeł historycznych. Kupiec nie jest tu konsekwentny i niekiedy posługuje się samymi nazwiskami, a niekiedy dodaje imiona. Jednak przywoływany w utworze repertuar nazwisk bardzo dobrze świadczy o erudycji i historycznym wykształceniu autora. 
Sejmiku jest oczywistą próbą polemiki z przesłaniem Trylogii. Kupiec, patrząc na dzieje Polski z perspektywy oczytanego śląskiego chłopa, boleśnie postrzega marginalizację znaczenia swojego stanu. Doskonale rozumie też, że każda próba demokratyzacji całego społeczeństwa musi być odebrana przez depozytariuszy dotychczasowych przywilejów jako zagrożenie. Ale nie widzi podstaw ani uzasadnień dla obrony dotychczasowego status quo. Przeciwnie, stara się udowodnić, że pozbawienie chłopów wpływu na rządy w państwie jest błędem. W tym zakresie jego polemika z postawą Sienkiewicza jest bardzo wyraźna, a przytaczane argumenty charakterystyczne. Gdy jeden z bohaterów Sejmiku w Jassach, Szymon Kossakowski, narzeka:

Więc projekt się zmienił w prawo

I nazwano go Ustawą

Lub raczej Konstytucyją,

I onej teraz użyją,

By z nas zrobić niewolniki

A chłopa zaś zrobić panem,

Wprowadzić razem z mieszczanem

Na sejmy i sejmiki ${ }^{18}$,

w obronie Konstytucji staje jedynie Michał Gliński ${ }^{19}$, starając się wytłumaczyć oponentom, że:

[...] nie dzieje się krzywda nikomu,

I nikt też nie jest poszkodowany,

Gdy chłopi razem z szlachtą i pany

Jako rodzina jednego domu,

Tak wszyscy nad tym już będą radzić,

Żeby w ojczyźnie ład zaprowadzićc ${ }^{20}$.

\section{Z takim stanowiskiem ostro polemizuje hetman Ksawery Branicki:}

Kniaziu, tak ważną sprawę traktujesz tak z lekka,

Nie zważając, że człowiek różny od człowieka.

${ }^{18}$ J. Kupiec, op. cit., s. 13.

${ }^{19}$ Michał Gliński, książę i marszałek nadworny litewski w latach 1500-1506, rozmaicie przedstawiany w polskiej historiografii, był m.in. bohaterem Śpiewów historycznych Juliana Ursyna Niemcewicza oraz dwóch utworów dramatycznych: Franciszka Wężyka (Gliński. Tragedia w 5 aktach wierszem) i Franciszka Kubali (Gliński - dramat historyczny w 4 aktach). Na to, że był on pierwowzorem bohatera poematu Kupca wskazywałyby m.in. słowa: „Żem zabił Jana Zabrzezińskiego / Do tego także się tu przyznaję" (J. Kupiec, op. cit., s. 65). Utwory te mógł znać Kupiec i na ich podstawie skonstruować postać magnata broniącego Konstytucji 3 maja i interesów chłopskich.

${ }^{20}$ J. Kupiec, op. cit., s. 62. 
Zważ no tylko, że ten chłop to jak ród króliczy,

Tak gęsty, że on się na miliony liczy,

A my, pany i szlachta to tak jak zające

W mniejszości, bo nas ledwo liczą na tysiące.

I tak przy kreskowaniu chłopi swym króliczym

Zwyciężą - pan i szlachcic wyjdą z urny z niczym,

$[\ldots]$

A powiada przysłowie, że nie ma większego

Na tym świecie tyrana, a w piekle szatana

Jak chłop, gdy się przypadkiem jakim zmieni w pana ${ }^{21}$.

$\mathrm{Na}$ argumenty Glińskiego, który przypomina, że chłopi są ostoją tradycji, że kochają ojczyznę i naród, Józef Kossakowski odpowiada:

Język ojczysty, obyczaj ludowy

I narodowość to tylko jest szata,

$[\ldots]$

Więc gdy ta szata taka rzecz znikoma,

To ją porzucić trzeba ze wzgardą;

$[\ldots]$

A porzucić ją tym lepiej im wcześniej:

Najlepiej wtedy, gdy się jest dzieciakiem,

Bo się mniej tęskni za tym marnym znakiem;

W latach późniejszych już to jest boleśniej ${ }^{22}$.

Magnaci podejmują w Jassach decyzję o zawiązaniu konfederacji targowickiej oraz przygotowują projekt nowej ustawy, która zachowuje liberum veto, wolną elekcję i wszystkie przywileje posesjonatów. I za to trafiają do piekła.

\section{Spór o historyczne znaczenie szlachty. Między apologia a krytyka}

Sejmik $w$ Jassach Kupca ma jasne przesłanie ideologiczne, obecne w tradycji polskiego romantyzmu: chłopi są podstawową siłą narodu, to oni - w przeciwieństwie do szlachty - są depozytariuszami najważniejszych wartości. Dzięki nim mają szanse przetrwać język i obyczaj, będące dla szlachty niewygodnym balastem. Trudno o bardziej wyrafinowaną polemikę z ideologią promowaną przez Sienkiewicza - przeciwko powieści historycznej, gatunkowi podówczas względnie nowemu i budzącemu zastrzeżenia („powieść historyczna w zakresie literatury jest tym samym, czym »prawdziwa kawa figowa« w zakresie handlu»23),

${ }^{21}$ Ibidem.

${ }^{22}$ Ibidem, s. 11.

${ }^{23}$ H. Sienkiewicz, O powieści historycznej, w: Trylogia Henryka Sienkiewicza. Studia, szkice, polemiki, oprac. T. Jodełka, Warszawa 1962, s. 238-239. Cytowany fragment dotyczy wypowiedzi Georga Brandesa (właśc. Georga Marrisa Cohena), na którego krytykę odpowiadał pisarz. 
skierowane zostało ostrze krytyki ubranej w formę trzynasto- $\mathrm{i}$ jedenastozgłoskowca, znaną i cenioną od Kochanowskiego do Mickiewicza. W poemacie Kupca magnaci oskarżają się sami - Sienkiewiczowska opowieść o bohaterskich rycerzach w Sejmiku w Jassach napotyka na opór świadomego własnej tożsamości chłopa, który bezbłędnie potrafi rozpoznać reguły skomplikowanej gry prywatnych i politycznych interesów.

Żeby zrozumieć to stanowisko, należałoby uwzględnić odmienność tradycji kultury chłopskiej na Śląsku i w Królestwie. Kupiec żyje w Księstwie Pszczyńskim, graniczącym z Księstwem Cieszyńskim (Pszczynę od Cieszyna dzieli około $50 \mathrm{~km}$ ), w którym od XVI wieku istniał obowiązek szkolny, a więc konieczność elementarnego nauczania wszystkich poddanych. W Cieszyńskiem na początku XX wieku biblioteczki chłopskie liczyły po kilkaset woluminów; znane są tzw. zapiśniki chłopskie pochodzące z XVIII wieku, a umiejętność czytania i pisania jest oczywistością ${ }^{24}$. To tu 9 listopada 1885 roku powołano Macierz Szkolną dla Księstwa Cieszyńskiego, z inicjatywy której do wybuchu I wojny światowej utworzono 71 szkół. Celem tej organizacji, która stała się wzorem dla twórców Polskiej Macierzy Szkolnej (1906), wśród których był także Sienkiewicz, było zachowanie polskości. Ten wzorzec promieniował na bliższą i dalszą okolicę, wytwarzając nawyki nieznane mieszkańcom wsi na innych ziemiach. Z perspektywy wykształconego chłopa, posiadającego świadomość swojej wartości i roli społecznej, marginalizacja tego stanu dokonywana w powieściach historycznych Sienkiewicza musiała budzić sprzeciw. Tymczasem najsławniejszy podówczas powieściopisarz, podobnie jak przeważająca część polskiej inteligencji, nie dostrzegał specyfiki Śląska i nie doceniał różnic kulturowych wynikających z kształtowania się samoświadomości chłopów w odmiennych warunkach. Podczas gdy Żeromski uznawał za wzruszające curiosum fakt, że podkieleccy wieśniacy słuchali fragmentów powieści Sienkiewicza odczytywanych przed pocztą, to na Śląsku chłopi czytywali te powieści samodzielnie, chociaż niekiedy w przeróbkach. I potrafili posługiwać się poprawną polszczyzną, bez naleciałości gwarowych. Analizując Sejmik... Kupca można odnieść wrażenie, że pisał go jeden z polskich romantyków; słaba przyległość pszczyńskiego poety do stereotypu Ślązaka i chłopa nie pozwala właściwie docenić głębi jego reakcji na propozycję Sienkiewicza. To sugerowałoby, że analiza recepcji Noblisty na Śląsku wymaga zastosowania specjalnych narzędzi; nie wystarczą w tym wypadku dane statystyczne.

${ }^{24}$ J. Broda, Zapiśniki chłopów cieszyńskich, „Regiony. Kwartalnik Społeczno-Kulturalny” 1978, nr 1. 


\title{
7. Zależności, zapożyczenia, wzorce stylistyczne
}

Wyrokiem historii twórczość Sienkiewicza przetrwała w powszechnej świadomości, podczas gdy twórczość Kupca znana jest nielicznym. Zmienić tego faktu nie można i niewiele pomagają tu niszowe badania prowadzone przez wąskie grono literaturoznawców zafascynowanych twórczością „polskiego wieszcza” 25 z Pszczyny. W poczet tych pasjonatów należy zaliczyć Walentego Ogrodzińskiego $^{26}$, Witolda Nawrockiego, a ostatnio dołączyła do nich Katarzyna Bizacka, dzięki której ujrzał światło dzienne rękopis Historii baranów, drugiego poematu Kupca, osnutego na kanwie dziejów Polski XVIII wieku ${ }^{27}$. Na trop potencjalnego wzorca stylistycznego obu poematów wskazała Mirosława Siuciak ${ }^{28}$, która badając je w aspekcie językowym stwierdza m.in., że Kupiec „może nawet wzorował się na Trylogii H. Sienkiewicza, w której archaizacja wypowiedzi bohaterów powstała w oparciu o XVII-wieczne Pamiętniki Jana Chryzostoma Paska"29. Autorka przywołała najbardziej charakterystyczne przykłady stylu, który mógł być oparty na barokowych oryginałach, ale równie dobrze na wypracowanym przez Sienkiewicza uproszczonym wzorcu stylizacyjnym:

\begin{abstract}
Alegoryczne odczytanie [Historii baranów] umożliwia język, wykorzystujący - jeszcze bardziej niż Sejmik w Jassach - elementy polszczyzny XVIII w. Najbardziej wyraziste aluzje do sejmów szlacheckich wzmacniane są zwrotami adresatywnymi, np., Panowie bracia! Zacni obory tej obywatele! Wspomnijcie waszmoście [...]. Zgodnie z zasadami etykiety staropolskiej zwraca się lis do baranów: Mości panowie! Wielmożni panowie!, do niedźwiedzi: Raczcie postuchać wielmożne asany. Także w bezpośrednich zwrotach do poszczególnych postaci obowiązuje model grzeczności zaczerpnięty z obyczajowości szlacheckiej, np. lis zwraca się do niedźwiedzia Wielmożny Boruto! ${ }^{30}$.
\end{abstract}

Przykłady te zdają się w dużym stopniu potwierdzać tezę o wpływie pisarstwa Sienkiewicza na styl poematów Kupca. W tym kontekście rodzi się pytanie o realny zakres poczytności nie tylko Krzyżaków, ale i Trylogii. Prawdopodobnie na Śląsku Cieszyńskim był on węższy niż w Królestwie, ale niewątpliwie także i tutaj Sienkiewiczowskie powieści historyczne czytane były, i to także w języku oryginału. Jednakże badanie recepcji tych utworów w omawianym rejonie wymaga wypracowania nowych narzędzi badawczych. Na pytanie o wpływ pisarza na sposoby myślenia i odczuwania Ślązaków nie odpowiedzą kwerendy uwzględniające wyłącznie dane bibliograficzne. Mamy tu bowiem do czynienia

\footnotetext{
${ }^{25}$ Napis na grobie Jana Kupca.

${ }^{26}$ W. Ogrodziński, Dzieje piśmiennictwa śląskiego, Katowice 1965.

${ }^{27}$ K. Bizacka, „Historia baranów” Jana Kupca z Łąki, Pszczyna-Łąka 2009.

${ }^{28}$ M. Siuciak, Język poematów Jana Kupca, w: W kręgu języka i kultury ziemi pszczyńskiej, red. H. Synowiec, M. Siuciak, Katowice-Suszec 2000.

${ }^{29}$ Ibidem, s. 64.

${ }^{30}$ Ibidem, s. 60-62.
} 
z modelem recepcji, którą można by określić mianem „gniazdowej”. Oznacza to, że spektakularne przykłady znaczenia lektury dla pojedynczych czytelników przekształcane bywają nie tylko w swoiste symbole odradzania dawnych rodzinnych związków z ojczyzną, ale i stają się zaczynem fascynacji samym zjawiskiem restytucji świadomości narodowej i siłą jej oddziaływania. Przypadek von Olszewskiego jest inny niż przypadek górnośląskiego chłopa piszącego do warszawskiej gazety, ale oba poświadczają to samo - utwory Sienkiewicza wydobywają z zapomnienia poczucie narodowej wspólnoty. Natomiast przypadek Kupca pokazuje, że człowiek, który to poczucie odbudowywał w sobie wcześniej, także w oparciu o słowo pisane, który umie docenić piękno polszczyzny i imitować język epoki, może jednocześnie zastosować zapożyczone frazy do zbudowania ideologii alternatywnej, w której koncepcja narodu przybiera szerszą i w istocie bardziej nowoczesną postać. Kupiec rozumie interesy, którymi kierują się elity szlacheckie, i próbuje przeciwstawić im wizję demokracji ponadstanowej. Ale zdaje się nie rozumieć, że jego idea, choć atrakcyjna społecznie, nie jest w równym stopniu fascynująca literacko, godzi bowiem nie tylko w szlacheckie przywiązanie do tradycji, do nabytych praw i przywilejów, ale i w chłopskie wyobrażenia możliwości lepszego losu, bohaterstwa, imperatywu obrony tego, co swoje, i dystansu do osobistej odpowiedzialności za to, co wspólne.

Początek XX wieku stał się widownią ruchów i przemian rewolucyjnych. Jan Kupiec aksjologicznie wpisywał się w ten nurt, ale zdawał się nie pojmować, że podjęta przez niego polemika z Sienkiewiczem mogła być jednocześnie odbierana jako uderzenie w to, co pisarz zdołał odbudować i zespolić siłą swojego talentu. Być może stanowisko Kupca zrozumiałby Gombrowicz, ale ten przyszedł na świat w dwa miesiące po tym, jak „Gazeta Opolska” skończyła drukować Sejmik w Jassach. Polskie drogi nie zawsze się krzyżują, a wartościowe i twórcze propozycje nie zawsze trafiają w odpowiednim czasie do właściwego odbiorcy. Dlatego powszechny odzew na indywidualną propozycję jest w naszej kulturze fenomenem bezwzględnie godnym uwagi.

\section{Bibliografia}

A. C., Testament von Olszewskiego, „Kurier Warszawski” 1932, nr 314.

Adamek-Świechowska, Adrianna, „Krzyżacy” i budzenie polskości, „Niedziela Ogólnopolska” 2009, nr 30.

Antkowiak, Zygmunt, Legenda warmatowicka. Rzecz o zapisie Alfreda Olszewskiego dla Henryka Sienkiewicza, Wrocław 1978.

Birkenmajer, Józef, Sienkiewicz a Ślask, „Zaranie Śląskie” 1934, nr 4.

Bizacka, Katarzyna, „Historia baranów” Jana Kupca z Łąki, Pszczyna-Łąka 2009. 
Brockhaus Enzyklopädie in vierundzwanzig Bänden. Neunzehnte, völlig neu bearbeitete Auflage, t. 20: Sci-Sq, Mannheim 1963.

Broda, Jan, Zapiśniki chłopów cieszyńskich, „Regiony. Kwartalnik Społeczno-Kulturalny” 1978, nr 1.

Henryk Sienkiewicz. Biografia - Twórczość - Recepcja, red. L. Ludorowski, H. Ludorowska, Lublin 1998.

Kosętka, Halina, O recepcji „Krzyżaków” Henryka Sienkiewicza, w: W stulecie „Krzyżaków” Henryka Sienkiewicza, red. L. Ludorowski, H. Ludorowska, Kielce 2000.

Kosman, Marceli, Wobec carskiej cenzury i pruskiego Drang nach Osten, w: idem, Henryka Sienkiewicza wizja Polski wspaniałej. Studia i szkice, Poznań 1999.

Kosowska, Ewa, Zagubiony kontekst, w: Na obrzeżach polityki, red. M. Kosman, cz. 1, Poznań 2002.

Kraushar, Tadeusz, Testament Olszewskiego, „Kurier Warszawski” 1924, nr 300.

Krzyżanowski, Julian, Henryk Sienkiewicz. Kalendarz życia i twórczości, uzupełniła i oprac. M. Bokszczanin, Warszawa 2012.

Kupiec, Jan, Sejmik w Jassach, wstęp i oprac. D. Rott, A. Spyra, Pszczyna 2010.

[List do Henryka Sienkiewicza], „Kurier Codzienny” 1900, nr 353.

Ludorowski, Lech, Antypruska publicystyka Henryka Sienkiewicza, Lublin 1996.

Ludorowski, Lech, Obywatelska stużba Sienkiewicza, w: Studia Sienkiewiczowskie, red. L. Ludorowski, H. Ludorowska, t. 1: Henryk Sienkiewicz. Biografia - Twórczość Recepcja, Lublin 1998.

Miarka, Karol, [List do redaktorów], „Gazeta Polska” 1879, nr 270.

Nawrocki, Witold, Jan Kupiec - poeta z Łąki, Katowice 1963.

Ogrodziński, Walenty, Dzieje piśmiennictwa śląskiego, Katowice 1965.

Pisma Henryka Sienkiewicza, Dwie łąki i inne nowele, Warszawa 1912.

Ratter, Bożena, Korzenie von Olszewskiego, http://solidarni2010.pl/11497-bozena-ratterkorzenie-von-olszewskiego.html?PHPSESSID =8d19c419652c42b7bf5f685fd6fab085 (d.d. 10.10.2018).

Rozprawa o „Krzyżaków” w krakowskim trybunale karnym, „Czas” 1901, nr 279.

Sienkiewicz, Henryk, Dzieła, red. J. Krzyżanowski, t. 53: Sprawy pruskie, Warszawa 1952.

Sienkiewicz, Henryk, O powieści historycznej, w: Trylogia Henryka Sienkiewicza. Studia, szkice, polemiki, oprac. T. Jodełka, Warszawa 1962.

Sienkiewicz, Henryk, Listy, oprac., wstęp i przyp. M. Bokszczanin, t. 3, cz. 1, Warszawa 2007.

Siuciak, Mirosława, Język poematów Jana Kupca, w: W kręgu języka i kultury ziemi pszczyńskiej, red. H. Synowiec, M. Siuciak, Katowice-Suszec 2000.

Szczublewski, Józef, Żywot Sienkiewicza, Warszawa 1989.

EwA KosowsKa, prof. dr hab., filolog i kulturoznawca; pracuje w Instytucie Nauk o Kulturze na Wydziale Humanistycznym Uniwersytetu Śląskiego. Członek Komitetu Nauk o Kulturze PAN od 2004 r., członek-założyciel Polskiego Towarzystwa Kulturoznawczego (prezes w latach 2013-2018), kierownik Zakładu 
Teorii i Historii Kultury w latach 1992-2016. Zajmuje się problemami z obszaru teorii i historii kultury, ze szczególnym uwzględnieniem możliwości wykorzystywania tekstu literackiego w badaniach antropologiczno-kulturowych. Autorka i redaktorka kilkunastu książek oraz licznych artykułów. Opublikowała m.in.: Postać literacka jako tekst kultury. Rekonstrukcja antropologicznego modelu szlachcianki na podstawie „Potopu” Henryka Sienkiewicza (1990), Negocjacje i kompromisy. Antropologia polskości Henryka Sienkiewicza (2002), Antropologia literatury (2003), Antropologia kultury - antropologia literatury (red., 2005), Stąd do Teksasu (2006), Antropologia kultury - antropologia literatury. Na tropach koligacji (red., 2007), Wstyd w kulturze (red.; t. 1, 1998; t. 2, 2008), Eurosarmata. O postawach $i$ wyborach Henryka Sienkiewicza (2013), Miłośnicy Melpomeny. Kartki z dziejów Towarzystwa Kultury Teatralnej w Katowicach (red., 2019). 